\title{
Evaluation of Single Slop Solar Still Integrated With Evaporative Cooling System for Brackish Water Desalination
}

\author{
Emad A. Almuhanna ${ }^{1}$ \\ ${ }^{1}$ Department of Agricultural Systems Engineering, College of Agricultural sciences and food, King Faisal \\ University, Saudi Arabia \\ Correspondence: Emad Ali Almuhanna, Department of Agricultural Systems Engineering, College of \\ Agricultural sciences and food, King Faisal University, Saudi Arabia. E-mail: ealmuhanna@kfu.edu.sa
}

\author{
Received: October 23, 2013 Accepted: November 11, 2013 Online Published: December 15, 2013 \\ doi:10.5539/jas.v6n1p48 URL: http://dx.doi.org/10.5539/jas.v6n1p48
}

\begin{abstract}
The thermal performance of a single slope (SS) solar still integrated with a condenser supplied with cooled water from an evaporative cooling system under hot and humid climatic conditions were studied and analyzed. Results of this study shows that the solar energy available inside the still with and without condenser resulted in an increase in the brackish water temperatures of $8.1{ }^{\circ} \mathrm{C}$. It also increased the temperature of the water vapor inside the still by $12.7^{\circ} \mathrm{C}$. Due to increase in the intensity of solar radiation and consequently the heat energy stored inside the single slope solar still, the productivity of distilled water was $5941.4 \mathrm{ml} / \mathrm{m}^{2}$ day. The thermal efficiency of the (SS) still without using condenser was on, an average, $54.4 \%$. Connecting the solar still to a condenser led to an increase in the productivity and thermal efficiency to $55.41 \%$ and $30.1 \%$, respectively. The obtained data also revealed that the $\mathrm{pH}(7.9), \mathrm{EC}(43.4 \mu \mathrm{s} / \mathrm{cm})$, and TDS (30.9 ppm) values were lower than those of the brackish water $(8.1,1,436$ $\mu \mathrm{s} / \mathrm{cm}$, and $1,370 \mathrm{ppm}$, respectively).
\end{abstract}

Keywords: solar still, single slope, condenser, evaporative cooling system

\section{Introduction}

Water is one of the most abundant natural resources on earth, and it covers three-quarters of the earth's surface. However, approximately $97 \%$ of the earth's water is salt water in the seas and oceans, and a tiny $3 \%$ is freshwater. This small percentage of the earth's water, which supplies the needs of humans, animals, and plants, mainly exists in groundwater, lakes, and rivers. Approximately $25 \%$ of the world does not have access to the necessary quality and quantity of freshwater, and more than 80 countries face severe water problems (Badran \& Abu-Khader, 2007).

The global freshwater shortage, particularly in remote areas, presents an international problem. The problem is more severe in desert countries, such as the Gulf Cooperation Council (GCC) countries and, in particular, the Kingdom of Saudi Arabia (KSA), where freshwater shortages are a serious problem (Radhwan, 2004). Many of these countries, however, enjoy abundant and free high-intensity solar energy, so solar desalination might be an ideal technology that could provide some freshwater for both domestic and agricultural use. Solar distillation is one of the many processes that can be used for water purification. Among all the alternative energy resources, solar energy is one of the most promising of all the sources because of its potential to provide for our future energy needs. Many developing countries that normally could not afford to use desalinated water are likely to have much greater water needs due to population growth. These countries, in general, also receive a greater amount of solar radiation. For example, the daily average solar radiation flux incident on Saudi Arabia is $5-8 \mathrm{kWh} / \mathrm{m}^{2}$ (Al-Ansari, 2013).

Solar radiation can be used as a source of heat energy in a process in which brackish or seawater is evaporated and then condensed as pure water (Hepbasli \& Alsuhaibani, 2011). The Kingdom of Saudi Arabia (KSA) lies between the latitude angles of $17.5^{\circ} \mathrm{N}$ and $31^{\circ} \mathrm{N}$ and the longitude angles of $36.6^{\circ} \mathrm{E}$ and $50^{\circ} \mathrm{E}$. This means that KSA is located in the heart of one of the world's most productive solar regions, which receives the most potent type of sunlight. The annual average solar radiation falling on the Arabian Peninsula is approximately $2.2 \mathrm{MWh} / \mathrm{m}^{2}$ (Hepbasli \& Alsuhaibani, 2011). KSA is an arid desert country, and there are no perennial rivers or streams or permanent freshwater lakes. The rainfall is both scarce and infrequent and is associated with high evaporation and sandy land dissipation rates. The available groundwater supplies are deeply buried and do not replenish themselves (Radhwan \& Fath, 2005). The many practical uses of solar energy in Saudi Arabia include lighting, cooling, 
cooking, water heating, crop and fruit drying, water desalination, operating irrigation pumps and meteorological stations, road and tunnel lighting, traffic lights, and road instruction signals (Hepbasli \& Alsuhaibani, 2011).

A solar pond (SP) is a stable pool of salt water in which the water salinity increases in the middle layer from its top to the bottom with a gradient that prevents convective temperature mixing. Heat is passively collected and stored in the lower convective zone because the middle layer is a nonconvective zone (Arjunan et al., 2009). Most commercial multistage flash (MSF) units operate with a top brine temperature of $90-110^{\circ} \mathrm{C}$, heated by steam, whereas the solar pond operates in the range of $30-95^{\circ} \mathrm{C}$. Therefore, in solar pond-assisted multistage flash (MSF) systems, the first stage of MSF heat exchangers is changed to a liquid-liquid heat exchanger instead of a steam-liquid heat exchanger (Micale et al., 2009). Because a solar pond combines solar collection and storage, it overcomes the intermittent nature of solar energy. However, the solar pond has to be oversized for winter conditions, necessitating that some of the surplus summer heat be wasted. As an alternative, waste heat energy from other sources (gas turbine, for example) may be used during periods of insufficient sunshine (Agha, 2009). These types of hybrid solar pond systems could store extra waste heat energy, such as from gas turbine exhaust during peak times to lower the freshwater production cost and the solar pond size (Tiwari et al., 2003; Drawish \& Alsairafi, 2004; Kalogirou, 2005; Li et al., 2013).

The thermal performance of a single basin solar still with the entering brine flowing between double glazing was investigated by Abu-Arabi et al. (2002). The main purpose of their arrangement was to lower the glass temperature and thus increase the temperature difference between the brine water and glass cover. This arrangement resulting in improved performance because a faster rate of evaporation from the basin of brine water was achieved. Utilization of solar energy with two different types of solar stills and the factors that influence the productivity of solar stills was studied by Al-Hayek and Badran (2004). They found that the productivity and efficiency of an asymmetric greenhouse-type still (ASGHT) having mirrors on its inside walls were higher than those of the symmetric greenhouse type still (SGHT).

Greenhouse technology is a breakthrough in agriculture production technology that integrates market-driven quality parameters with production system profits (Kumar et al., 2009). Protected cultivation in greenhouses has become the favored way to develop the agriculture sector due to the harsh climate and the scarcity and poor quality of water resources on the Arabian Peninsula (Hepbasli \& Alsuhaibani, 2011). In 2006, there was 5150 ha of greenhouses in Saudi Arabia producing 487,614 metric tons of vegetables (Alhamdan \& Al-Helal, 2009). Cooling is considered a basic necessity for greenhouse crop production in tropical and subtropical regions to overcome the problems of high temperatures during summer months (Kumar et al., 2009). Evaporative cooling involves no change in the enthalpy (heat content) of the air mixture. Rather, as water evaporates, it takes heat from the air, thus reducing its temperature. Evaporative cooling systems are based on the conversion of sensible heat into the latent heat of evaporated water, with the water supplied mechanically. Evaporative cooling has been used to improve human, plant, and animal comfort for many years in thermal environmental control applications. It remains one of the least expensive techniques that can be used to bring the air dry-bulb temperature into a more comfortable range. It is a reliable method and requires minimum power consumption (Ahmed et al., 2011). Greenhouses located in dry, desert environments benefit greatly from evaporative cooling systems because large amounts of water can be evaporated into the incoming air, resulting in significant temperature drops. The fan-pad system consists of a fan on one sidewall and a pad on the other sidewall of the greenhouse. The principle of evaporative cooling is applied by running a water stream over the pad, followed by drawing air through the pad using fans on the opposite side. The fan-pad cooling produces two changes in the condition of air exiting the pads. The air becomes cooler and its humidity is also raised (Sethi \& Sharma, 2007). As a result, the water draining from the cooling pads will have a lower temperature. Abdel-Rehim and Lashine (2012) concluded that combining the solar still with the air-conditioning system could increase the condensate output from the solar still while meeting the cooling load needs. Fath and Hosny (2002) used shielded separate condenser to increase the productivity of solar still.

The main objectives of the present work are to investigate and to evaluate the various parameters affecting both the thermal efficiency and the productivity of single slope solar still, and to study the effect of integration using condenser supplied with cooled water from an evaporative cooling system on the performance of the solar stills.

\section{Materials and Methods}

A single slope solar still was designed, constructed, and tested during May 2013 at the Agricultural and Veterinary training and Research Station of King Faisal University, Saudi Arabia (Latitude angle $25.3^{\circ} \mathrm{N}$, longitude angle $49.5^{\circ} \mathrm{E}$, and mean altitude above sea level $172 \mathrm{~m}$ ). The geometric characteristics of the single slope still are as follows: width, $1.0 \mathrm{~m}$; length, $2.0 \mathrm{~m}$; still rafter angle, $35^{\circ}$; rafter length, $1.22 \mathrm{~m}$; gable height, $0.7 \mathrm{~m}$; basin height, $0.2 \mathrm{~m}$; and basin surface area, $2.0 \mathrm{~m}^{2}$, as demonstrated in Figure 1. 


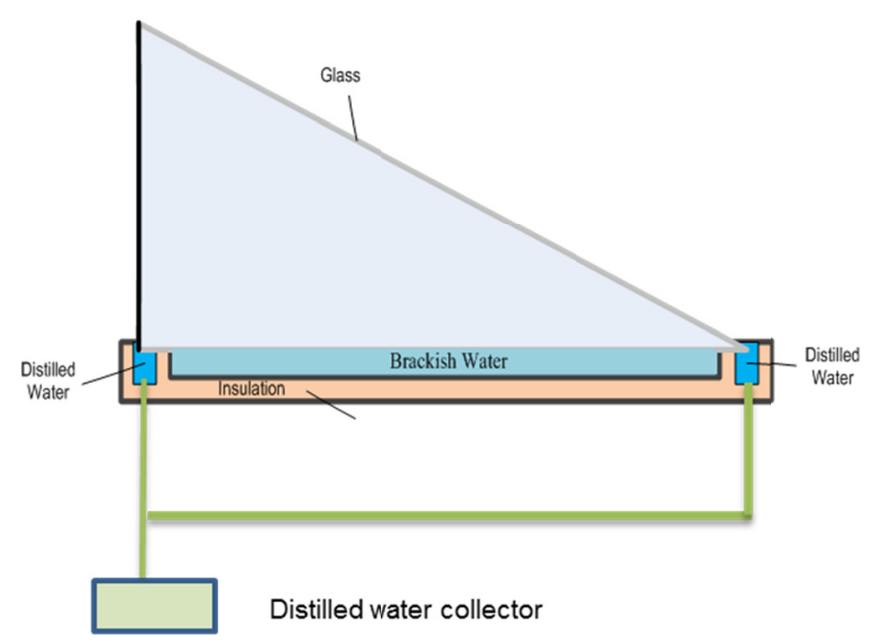

Figure 1. Single slope (SS) solar still [Figures, not drawn to scale]

Basin liner of the solar still is made of a galvanized stainless-steel sheet $1.5 \mathrm{~mm}$ thick with a maximum height of 20 $\mathrm{cm}$. The galvanize basins was painted by red-lead primer and then by matte-type black paint to maximize the absorbed solar radiation. The bottom and sides of the solar still was insulated from outside with rock wool insulation $5 \mathrm{~cm}$ thick, with a thermal conductivity of $0.045 \mathrm{~W} / \mathrm{m} \cdot{ }^{\circ} \mathrm{C}$ to minimize the heat loss from the bottom and side walls of the solar still into the surroundings. The solar still was covered by $3 \mathrm{~mm}$ thick clear glass with a maximum effective transmissivity of 0.90 . Experimental results showed that a solar still with a glass cover plate 3 $\mathrm{mm}$ thick was $16.5 \%$ more productive than the still with a glass cover $6 \mathrm{~mm}$ thick (Murugavel et al., 2008). The following specifications are required for the glass cover used in the solar still: minimum amount of absorbed heat energy, minimum amount of reflection for solar radiation, maximum transmittance for solar radiation, and high thermal resistance for heat loss from the basin to the surroundings. The glass cover has been sealed with silicone rubber, which plays an important role in promoting efficient condensation operations because it can accommodate the expansion and contraction between dissimilar materials. The solar still was orientated in an East-West direction, with the southern longitudinal side facing the sun's rays. A small feeding tank was located beside the still as a constant head tank, which was used to control the level of brackish water inside the solar still to maintain the water level in the basin constant over time using a floating ball $2.5 \mathrm{~cm}$ deep. For the duration of the experimental work, the volume of brackish water in the basins was maintained at 50 liters.

In the operation of the solar still, solar radiation was transmitted through the glass cover and absorbed by the brackish water and the bottom of the basin. The sensible heat absorbed by the brackish water was used to evaporate the water, which transferred to the glass as water vapor, where it was condensed on the underside of the glass cover (water vapor condenses in a film on the inside surface, that is, at a temperature below the dew-point temperature of the inside moist air). Another part of the heat from water was transferred to the glass cover by free convection using air; the remaining heat was transferred by radiation. The glass cover transferred the heat to the atmosphere by convection and radiation. Some heat energy accumulated in the solar still in the form of the sensible heat of the still and water. Some heat energy may be lost due to leakage of water vapor and water from the still. Condensate water flowed via gravity into the collection trough at the lower edges of the tilted glass cover (the glass cover was at a sufficient slope $\left(35^{\circ}\right)$; therefore, the surface tension of the water caused it to flow into the trough without dropping back into the basin). Two plastic containers were used to collect the distilled water coming out of the solar still. Brackish water with $\mathrm{pH}, \mathrm{EC}$, and TDS values $(8.1,1,436 \mu \mathrm{s} / \mathrm{cm}$, and $1,370 \mathrm{ppm}$, respectively) was used as the feed; the concentration was usually allowed to double before the brackish water was removed, so half of the water in the feed was distilled off.

To enhance and improve the thermal performance of the solar stills, it was connected to a condenser. The basic operation of the condenser is dependent upon the cooled water (water temperature at the wet-bulb temperature of the ambient air) coming from the water storage tank of the greenhouse evaporative cooling system, which was situated beside the solar still, as shown in Figure 2. The condenser was located $0.8 \mathrm{~m}$ from the evaporative cooling system to provide and maintain the cooled water at a lower temperature. It consisted of two cylindrical tubes made of galvanized stainless-steel sheet $1.5 \mathrm{~mm}$ thick. The outer tube (cold-water cylinder) was $0.4 \mathrm{~m}$ in diameter, $1 \mathrm{~m}$ long, and covered with a glass wool insulation material, whereas the inner tube (water vapor) was $0.2 \mathrm{~m}$ in 
diameter and $1 \mathrm{~m}$ long, as revealed in Figure 3. The function of the condenser is to provide a surface temperature (inside surface of the inner tube) lower than the dew-point temperature of water vapor, consequently speeding up the condensation process and the phase-change water vapor into freshwater, as demonstrated in Figure 4.

An experimental gable-even-span greenhouse form was designed, constructed, and installed beside the solar still to utilize the evaporative cooling system being used to provide cooled water for the condenser. The geometric characteristics of the gable-even-span form were as follows: eaves height, $1.25 \mathrm{~m}$; gable height, $0.30 \mathrm{~m}$; span angle, $31^{\circ}$; width, $1.30 \mathrm{~m}$; length, $1.25 \mathrm{~m}$; floor surface area, $1.625 \mathrm{~m}^{2}$; and volume, $2.1 \mathrm{~m}^{3}$. The greenhouse structural frame was made of wooden plates $(0.05 \mathrm{~m} \times 0.05 \mathrm{~m})$. It was covered with a single polyethylene sheet $(\mathrm{PE}, \mathrm{UV}) 200$ $\mu \mathrm{m}$ thick. The greenhouse was orientated in the East-West direction. The evaporative cooling system consisted of one extracting fan with the following specifications: $0.4 \mathrm{~m}$ diameter and $900 \mathrm{~m}^{3} / \mathrm{h}$ discharge, $1 \mathrm{~m}^{2}$ of cooling pads, $0.16 \mathrm{~m}^{3}$ water reservoirs, and $1 / 3 \mathrm{hp}$ water pump.

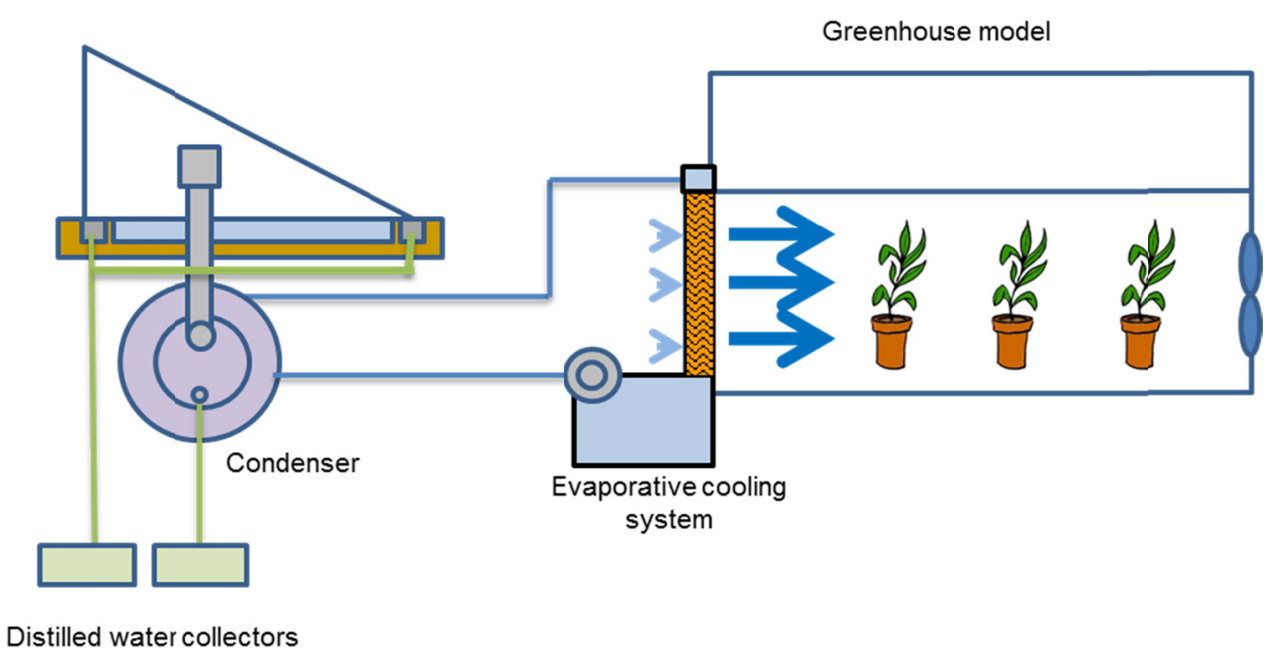

Figure 2. Single slope type (SS) solar still connected to a condenser [Figure, not drawn to scale]

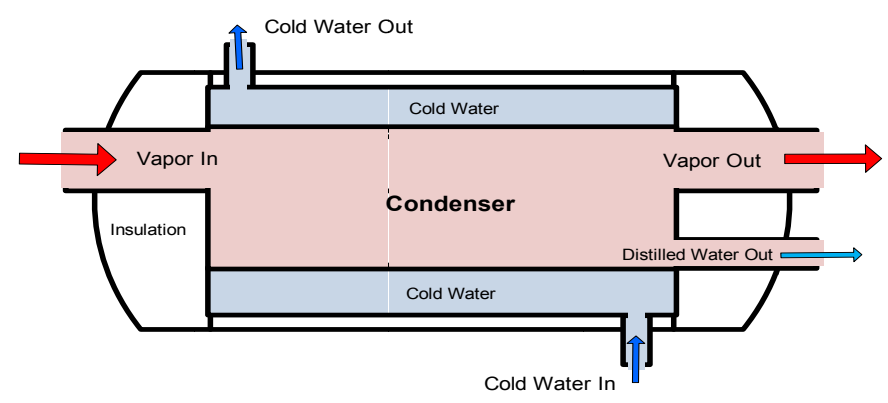

Figure 3. Schematic diagram of the condenser using cooled water from the evaporative cooling system [Figure, not drawn to scale] 

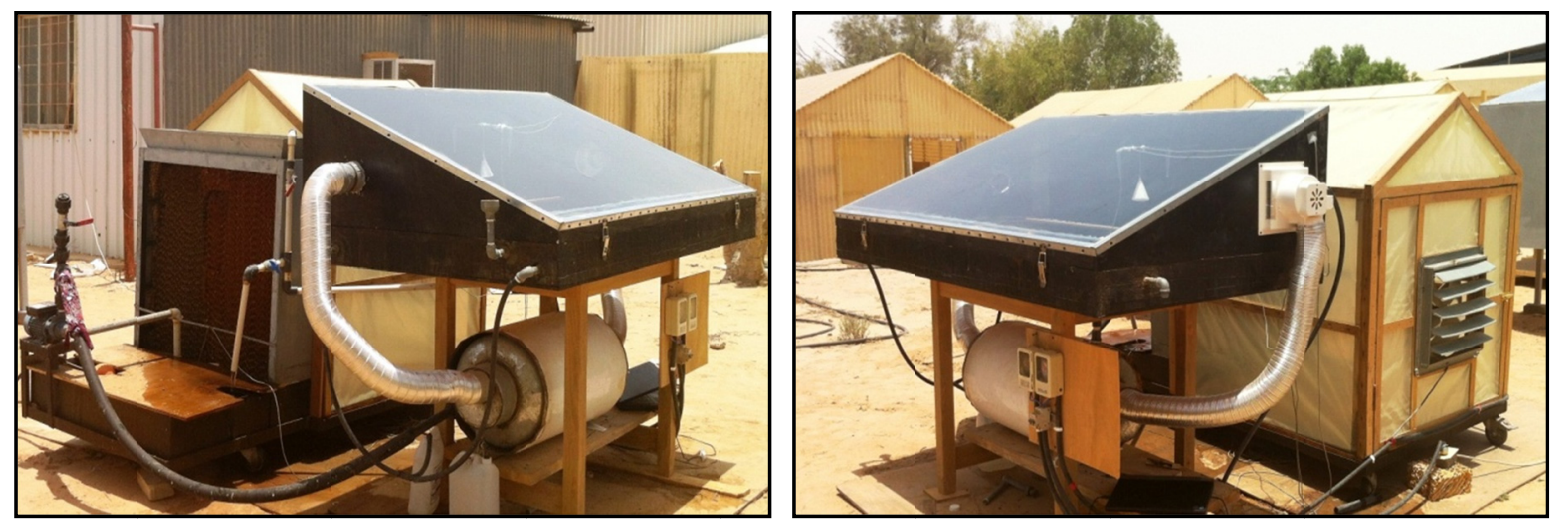

Figure 4. Single slope type (SS) solar still connected to a condenser

\subsection{Thermal Efficiency of the Solar Still}

The thermal efficiency of a solar still is defined as the ratio of the rate of heat transfer $\left(\mathrm{q}_{\mathrm{ev}}\right)$ in the still by evaporation-condensation $\left(\mathrm{W} / \mathrm{m}^{2}\right)$ to the solar radiation $(\mathrm{R})$ on the still $\left(\mathrm{W} / \mathrm{m}^{2}\right)$. It can be calculated by the following equation (ASHRAE, 2005; Duffie \& Beckman, 2006):

$$
\eta_{v o l}=\frac{q_{e v}}{R}
$$

This equation is usually integrated over some extended period (e.g., day or month) to indicate long-term performance. However, in practice, because there is some loss of product freshwater back into the basin of the still (by dripping from the glass cover and leakage from the collecting troughs), less product would be available than is indicated by the above equation. Therefore, the thermal efficiency of the solar still from the experimental measurements (volumetric thermal efficiency), which represents the productivity of freshwater, is mainly computed using the following equation (ASHRAE, 2005; Duffie \& Beckman, 2006):

$$
\eta_{v o l}=\frac{m_{p} h_{f g}}{3.6 A_{b} R}
$$

where $\mathrm{m}_{\mathrm{p}}$ is the rate at which the distillate of freshwater is produced from the still in $\mathrm{kg} / \mathrm{s}, \mathrm{h}_{\mathrm{fg}}$ is the latent heat of vaporization in $\mathrm{kJ} / \mathrm{kg}, \mathrm{A}_{\mathrm{b}}$ is the surface area of the basin in $\mathrm{m}^{2}$, and $\mathrm{R}$ is the solar radiation flux incident on the basin in $\mathrm{W} / \mathrm{m}^{2}$.

\subsection{Measurements and Data Acquisition}

Meteorological data, including the solar radiation flux incident on a horizontal surface, the air temperature, wind speed and direction, and the relative humidity of the air, were measured by a meteorological station (HOBO U30-NRC Weather Station, Onset Computer, USA).

Measurements inside the solar stills (ambient air temperature, $\mathrm{T}_{\mathrm{a}}$; brackish water temperature, $\mathrm{T}_{\mathrm{w}}$; still vapor temperature, $\mathrm{T}_{\mathrm{v}}$; inside glass temperature, $\mathrm{T}_{\mathrm{gi}}$; and outside glass temperature, $\mathrm{T}_{\mathrm{go}}$ ) of the solar radiation inside the solar still were carried out using external temperature sensors connected to the same system.

The hourly produced distilled water values were recorded for each hour using a graduated measuring cylinder $(1000 \mathrm{ml})$. Moreover, the quality parameters of the distilled water produced by the solar distiller, such as $\mathrm{pH}$, electrical conductivity (EC), and total dissolved solids (TDS), were measured.

\section{Results and Discussion}

The solar still was operated from 7.00 am to $17.00 \mathrm{pm}$ during the month of May 2013. The measurements of the solar radiation intensity, various temperatures, and the production of distilled water were taken each hour to study the effect of each parameter on the productivity of the solar still. In this study, various variables, such as the ambient air temperature $\left(T_{a}\right)$, glass cover temperature $\left(T_{g}\right)$, water vapor temperature, $\left(T_{v}\right)$, brackish water temperature $\left(T_{w}\right)$, intensity of solar radiation $(R)$, wind speed $(V)$, and productivity of distilled water were measured hourly. The total productivity of distilled water and intensity of solar radiation for each day (five days) were also measured. Different experimental tests were also executed at different ambient conditions. The mean wind speed was found to be approximately $3.2-5.8 \mathrm{~m} / \mathrm{s}$. 


\subsection{Case 1: Comparison of the Thermal Performance and Productivity of the Solar Still (Without Using a Condenser)}

Figure 5 reveals the hourly average intensity of solar radiation on the brackish water inside the solar still. The intensity of solar radiation gradually increased from sunrise until reaching the maximum value at noon, and then it gradually decreased until reaching the minimum value prior to sunset. For the duration of the experimental tests (five days), the hourly average intensities of solar radiation inside the single slope (SS) solar still was $631.5 \mathrm{~W} / \mathrm{m}^{2}$. The intensity of solar radiation has an important effect on the thermal performance of the solar still.

The volumetric thermal efficiency of the solar still is considered the most important factor to evaluate because it can reveal the best solar still design. The volumetric thermal efficiency for the solar still gradually increased from early morning (21.9\%) until it reached the maximum values $(69.2 \%)$ in the afternoon (at $14.00 \mathrm{hr}$ ), as illustrated in Figure 5. For the duration of the experimental tests, the hourly average volumetric thermal efficiency for the solar still was $54.4 \%$. At the maximum values, the intensity of solar radiation was higher than the heat energy losses early in the afternoon. Then, the heat energy losses became greater than the intensity of the solar radiation (which decreased over time in the afternoon). From the previous results, it can be concluded that as the intensity of solar radiation increased, the temperature difference between the brackish water and ambient air increased considerably due to the increase of the water temperature through the conduction process between the black surface of the basin and the brackish water. In the early morning, the temperatures of the brackish water were low; therefore, a large amount of solar energy was needed to change the phase from saturated liquid to the saturated vapor phase. The obtained data revealed that the water temperature and heat energy required are inversely proportional. In the early afternoon, the temperature of brackish water reached the maximum value (59.2), so less heat energy was needed to vaporize the liquid and vice versa in the late afternoon. The hourly average temperature differences between the vapor and the glass cover for the solar still was $10.8^{\circ} \mathrm{C}$.

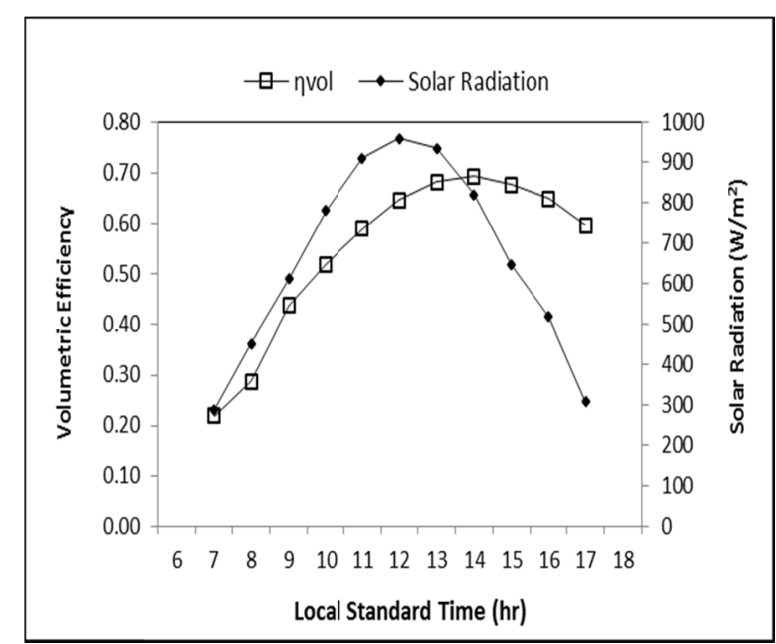

Figure 5. Volumetric thermal efficiency for the solar still, the intensity of solar radiation versus local standard time during the experimental tests

The experimental results from the solar still taken from five successive days are plotted in Figure 6. It can be clearly seen that an increase in the brackish water temperatures occurred until they reached the maximum values $\left(59.2^{\circ} \mathrm{C}\right)$ in the afternoon (at $14.00 \mathrm{hr}$ ) because the absorbed solar radiation exceeded the losses to the surrounding. After $14.00 \mathrm{hr}$, the brackish water temperature decreased because of the heat energy losses from the solar still, which became larger than the absorbed solar radiation. 


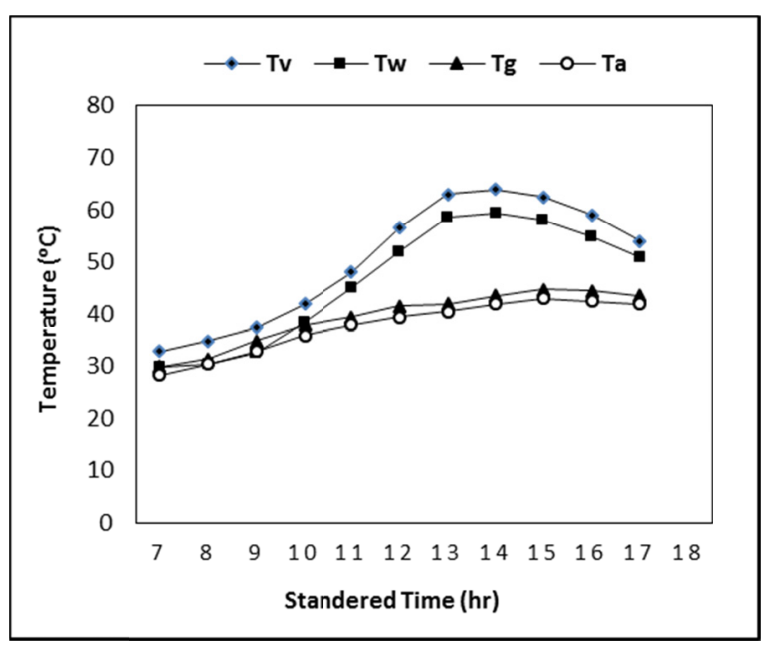

Figure 6. Various temperatures in the solar still versus local standard time during the experimental tests

Figure 6 reveals that the water vapor temperature was the largest temperature in the solar still because at this temperature, the particles have enough heat energy to evaporate. It can also be noticed from Figure 6 that the glass cover temperature was usually lower than that of the water vapor temperature, except in the early morning when the difference between them was very small. Because the glass cover temperature is much lower than the water vapor temperature, it caused condensation of vapor on the inside surface area of the glass. In the early morning hours $(7-9 \mathrm{am})$, the glass temperature was closest to the water and vapor temperatures, resulting in little productivity due to the small amount of heat energy absorbed by the water at these times.

As the intensity of the solar radiation inside the solar still increased, the productivity of freshwater increased due to the increase in heat energy gained for brackish water vaporization inside the still. The productivity rate of freshwater varied as time passed from early morning until late afternoon, as shown in Figure 7. It can be seen that the productivity of freshwater gradually increased from early morning $\left(77.4 \mathrm{ml} / \mathrm{m}^{2} \mathrm{hr}\right)$ until reaching the maximum values $\left(933.5 \mathrm{ml} / \mathrm{m}^{2} \mathrm{hr}\right.$ ) in the afternoon (at $13.00 \mathrm{hr}$ ). The productivity then decreased until reaching the minimum values $\left(274.4 \mathrm{ml} / \mathrm{m}^{2} \mathrm{hr}\right)$ just prior to sunset. The brackish water temperature can be considered one of the parameters that has a direct effect on the productivity of freshwater.

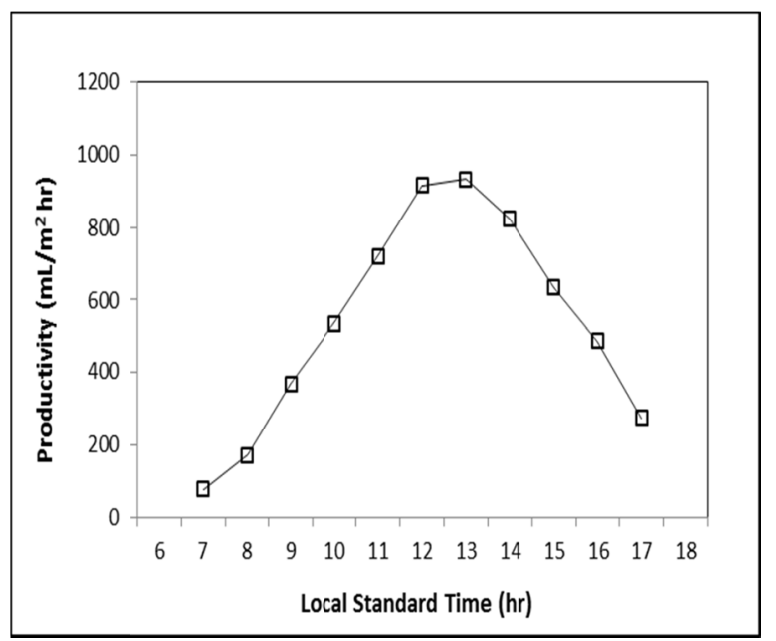

Figure 7. Productivity of freshwater for the solar still versus local standard time

\subsection{Case 2: Comparison of the Thermal Performance and Productivity of the Solar Still (With a Condenser)}

For the duration of this experimental test, a condenser was connected to the solar still to increase the rate of vapor condensation on the inner surface of the condenser. Each shell of the condenser (space between the inner and outer surfaces) was filled with cooled water from an evaporative cooling system attached to a small greenhouse. The 
cooled water temperature from the evaporative cooling system reservoir going to the condenser ranged from 18 to $25^{\circ} \mathrm{C}$. The means of various parameters within the solar still and the ambient air temperature during another five successive days were measured and are listed in Table 1 . The daily average intensity of solar radiation inside the solar still was $7.369 \mathrm{~kW} / \mathrm{m}^{2}$, which gave hourly average solar radiation intensities of $669.9 \mathrm{~W} / \mathrm{m}^{2}$. In spite of the fact that the maximum value of the solar radiation intensity during the experimental period occurred at and around noon, the brackish water and water vapor temperatures still increased until reaching the maximum values in the afternoon $(14.00 \mathrm{hr})$ because some heat energy accumulated inside the solar stills in the form of sensible heat. The temperatures of the glass covers of the solar still also increased from early morning until they approached the maximum values in the afternoon because part of the heat from the water was transferred to the glass cover by free convection using air, and the remaining part was transferred by radiation. The glass covers transferred the heat into the atmosphere by convection and radiation. Lowering the glass cover temperatures below the water and outside air temperatures helped increase the rate of heat and mass transfer. The temperature difference between the glass covers of the still and the basin brackish water increased, which increased the natural circulation of the air mass inside the two stills. The natural circulation increased both the convective and evaporative heat transfer between the basin brackish water and glass cover.

Table 1. Hourly average ambient air temperature $\left(\mathrm{T}_{\mathrm{a}}\right)$, intensity of solar radiation $(\mathrm{R})$, water temperature $\left(\mathrm{T}_{\mathrm{w}}\right)$, water vapor temperature $\left(T_{v}\right)$, condenser water temperature $\left(T_{C o n d}\right)$, and glass cover temperature $\left(T_{g}\right)$ for the single slope solar still during the experimental tests days

\begin{tabular}{lllllll}
\hline Local standard time & $\mathrm{T}_{\mathrm{a}},{ }^{\circ} \mathrm{C}$ & $\mathrm{R}, \mathrm{W} / \mathrm{m}^{2}$ & $\mathrm{~T}_{\mathrm{w}},{ }^{\circ} \mathrm{C}$ & $\mathrm{T}_{\mathrm{v}},{ }^{\circ} \mathrm{C}$ & $\mathrm{T}_{\mathrm{g}},{ }^{\circ} \mathrm{C}$ & $\mathrm{T}_{\mathrm{Cond}},{ }^{\circ} \mathrm{C}$ \\
\hline 7.00 & 31.6 & 264.2 & 32.3 & 35.5 & 33.3 & 22.5 \\
8.00 & 34.9 & 401.1 & 36.3 & 40.0 & 36.7 & 24.5 \\
9.00 & 37.6 & 639.2 & 39.5 & 43.5 & 40.1 & 25.1 \\
10.00 & 40.4 & 821.6 & 46.1 & 50.7 & 42.4 & 26 \\
11.00 & 42.9 & 928.7 & 53.7 & 59.1 & 45.0 & 26.6 \\
12.00 & 44.2 & 971.4 & 62.8 & 69.2 & 46.4 & 27.4 \\
13.00 & 45.1 & 947.1 & 70.8 & 77.9 & 47.4 & 28.1 \\
14.00 & 46.3 & 816.7 & 71.9 & 79.1 & 48.6 & 28.5 \\
15.00 & 46.7 & 726.8 & 70.1 & 77.2 & 48.0 & 28.5 \\
16.00 & 45.4 & 542.6 & 66.6 & 73.3 & 46.6 & 28.1 \\
17.00 & 44.1 & 309.8 & 62.4 & 68.6 & 45.3 & 27.2 \\
\hline Total & - & 7369.2 & - & - & - & - \\
\hline Mean & 41.7 & 669.9 & 55.7 & 61.3 & 43.6 & 26.6 \\
\hline
\end{tabular}

Figure 8 illustrates the productivity of freshwater for the solar still with and without using a condenser. The productivity rate of freshwater varied as time passes from early morning until late afternoon for both systems. Using the condenser with the solar still resulting in an increase in the condensed freshwater rate because the cooler inner surface of the condenser increased the rate of condensation. The daily average productivity of freshwater for the single slope solar still connected to a condenser increased from 5.9414 to $9.2333 \mathrm{~L} / \mathrm{m}^{2}$ day, which gave an increasing rate of $55.41 \%$. Because the inner surface temperatures of the two condensers were much smaller than the water vapor temperature, they caused an increasing condensation rate on the inner surfaces. In the early hours of the morning (7-8 am), the temperature difference between the inside parameters (brackish water and water vapor temperatures) of the solar still and the inner surface of the condenser was lower than at other times, which resulted in low freshwater productivity. 


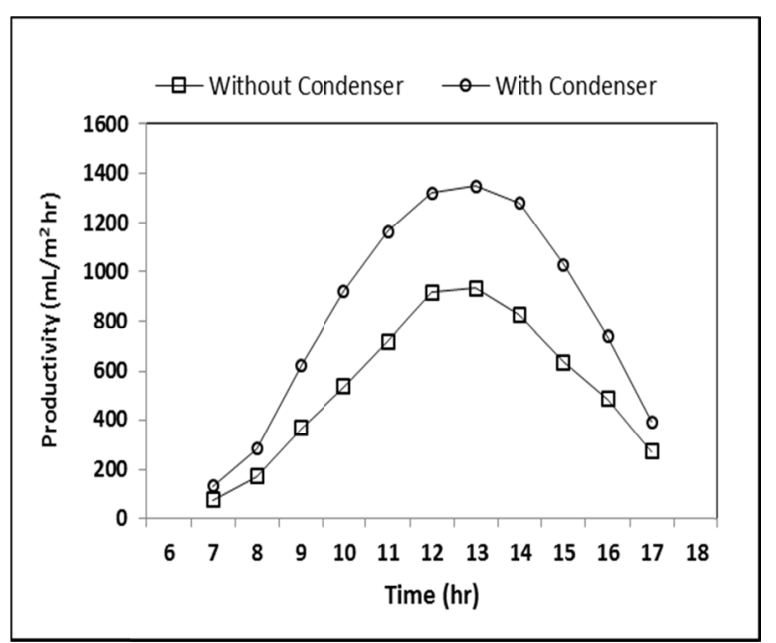

Figure 8. Freshwater productivity versus local standard time with and without using a condenser for the single slope (SS) solar still during the experimental tests

The volumetric thermal efficiencies for the solar still using a condenser gradually increased with time from the early morning (36.4\%) until they reached the maximum values (104.6\%) in the late hours of the afternoon (at 14.00 hr), as illustrated in Figure 9. For the duration of the experimental tests, the hourly average volumetric thermal efficiencies for the solar still using a condenser was $84.5 \%$. The condenser was dimensioned according to the cover material used for conducting and convecting the latent heat of condensation at the inner surface of the condenser. The condenser utilized circular shells to enhance the convection heat transfer and consequently increased the rate of productivity and volumetric thermal efficiency. Therefore, using a condenser with the solar still resulted in an increase in the volumetric thermal efficiency by $30.1 \%$, compared with the efficiencies of the solar still used without a condenser.

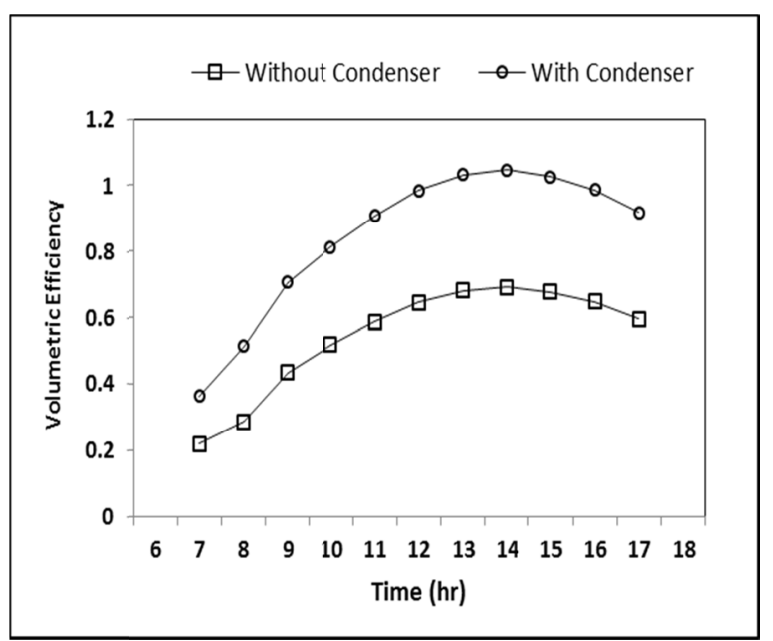

Figure 9. Volumetric thermal efficiency for the solar still with and without a condenser versus local standard time during the experimental tests

\subsection{Quality of Distilled Water}

The $\mathrm{pH}, \mathrm{EC}$, and TDS values of the brackish water and solar distilled water obtained from the experimental tests are summarized and listed in Table 2. These values were found to be much lower $(7.9,43.4 \mu \mathrm{s} / \mathrm{cm}$, and $30.9 \mathrm{ppm}$, respectively) than those of the brackish water $(8.1,1436 \mu \mathrm{s} / \mathrm{cm}$, and $1370 \mathrm{ppm}$, respectively). The quality of water distilled from the solar still is suitable for producing drinking water, particularly in remote areas. 
Moreover, produced distilled water can be added to the evaporative cooling system reservoir that will help in reducing salts build up on the cooling pads (pads clogging) and enhance the pads life suggesting that this system can be integrated to the evaporative cooling system.

Table 2. Quality parameters ( $\mathrm{pH}, \mathrm{EC}$, and TDS) of the solar distilled water and brackish water during the experimental tests

\begin{tabular}{lll}
\hline Parameter & Brackish water & Distilled water \\
\hline $\mathrm{pH}$ & 8.1 & 7.9 \\
Electrical conductivity (EC), $\mu \mathrm{s} / \mathrm{cm}$ & 1436 & 43.4 \\
Total Dissolved Solids (TDS), ppm & 1370 & 30.9 \\
\hline
\end{tabular}

\section{Conclusions}

In the present research work, several conclusions can be drawn:

1) The increase in either the intensity of solar radiation and/or the ambient air temperature can lead to an increase in the productivity of a single slope solar still.

2) As the intensity of the solar radiation inside the solar still is increased, the productivity of freshwater increased due to the increase in heat energy gained from brackish water vaporization inside the still.

3) The maximum productivity and efficiency for single slope solar still occurred in the early afternoon due to the high heat energy accumulated inside the solar still at this time.

4) The proposed technique of using a condenser that provides cooled water to increase the productivity of potable water significantly increases the productivity and volumetric thermal efficiency of the solar still.

\section{References}

Abdel-Rehim Z. S., \& Lashine, A. (2012). A Study of Solar Desalination Still Combined with Air-Conditioning System. ISRN Renewable Energy, International Scholarly Research Network.

Abu-Arabi, M., Zurigat, Y., Al-Hinai, H., \& Hiddabi, S. (2002). Modeling and performance analysis of a solar desalination unit with double-glass cover cooling. Desalination, 143, 173-182. http://dx.doi.org/10.1016/S0011-9164(02)00238-2

Agha, K. R. (2009). The thermal characteristics and economic analysis of a solar pond coupled low temperature multi-stage desalination plant. Solar Energy, 83, 501-510. http://dx.doi.org/10.1016/j.solener.2008.09.008

Ahmed, E. M., Abaas, O., Ahmed, M., \& Ismail, M. R. (2011). Performance evaluation of three different types of local evaporative cooling pads in greenhouses in Sudan. Saudi Journal of Biological Sciences, 18, 45-51. http://dx.doi.org/10.1016/j.sjbs.2010.09.005

Al-Ansari, M. S. (2013). Concentrating solar power to be used in seawater desalination within the Gulf Cooperation Council. Energy and Environment Research, 3(1), 10-23.

Alhamdan, A. M., \& Al-Helal, I. M. (2009). Mechanical deterioration of polyethylene greenhouse covering under arid conditions. Journal of Materials Processing Technology. 209, 63-69. http://dx.doi.org/10.1016/j.jmatprotec.2008.01.052

Al-Hayek, I., \& Badran, O. O. (2004). The effect of using different designs of solar stills on water distillation. Desalination, 169(2), 121-127. http://dx.doi.org/10.1016/S0011-9164(04)00520-X

Arjunan, T. V., Aybar, H. S., \& Nedunchezhian, N. (2009). Status of solar desalination in India. Renewable and Sustainable Energy Review, 13, 2408-2418. http://dx.doi.org/10.1016/j.rser.2009.03.006

ASHRAE. (2005). Handbook of Fundamentals. American Society of Heating, Refrigerating and Air Conditioning Engineers, New York, USA.

Badran, O. O., \& Abu-Khader, M. M. (2007). Evaluating thermal performance of a single slope solar still. Heat mass Transfer, 43, 985-995. http://dx.doi.org/10.1007/s00231-006-0180-0

Darwish, M. A., \& Alsairafi, A. (2004). Technical comparison between TVC/MEB and MSF. Desalination, 170, 223-239. http://dx.doi.org/10.1016/j.desal.2004.01.006 
Duffie, J. A., \& Beckman, W. A. (2006). Solar engineering of thermal processes. New York, N.Y.: John Wiley and Sons.

Fath, H. E. S., \& Hosny, H. M. (2002). Thermal performance of a single-sloped basin still with an inherent built-in additional condenser. Desalination, 142, 19-27. http://dx.doi.org/10.1016/S0011-9164(01)00422-2

Hepbasli, A., \& Alsuhaibani, Z. (2011). A key review on present status and future directions of solar energy studies and applications in Saudi Arabia. Renewable and Sustainable Energy Reviews, 15, 5021-5050. http://dx.doi.org/10.1016/j.rser.2011.07.052

Kalogirou, S. M. (2005). Seawater desalination using renewable energy sources. Progress in Energy and Combustion Science, 31, 242-281. http://dx.doi.org/10.1016/j.pecs.2005.03.001

Kumar, K. S., Tiwari, K. N., \& Jha, M. K. (2009). Design and technology for greenhouse cooling in tropical and subtropical regions: A review. Energy and Buildings, 41, 1269-1275.

Li, C., Goswami, Y., \& Stefanakos, E. (2013). Solar assisted seawater desalination: A review. Renewable and Sustainable Energy Reviews, 19, 136-163.

Micale, G., Rizzuti, L., \& Cipollina, A. (2009). Seawater desalination conventional and renewable energy processes. Springer link.

Murugavel, K. K., Chockalingam, Kn., K. S. K., \& Srithar, K. (2008). Progresses in improving the effectiveness of the single basin passive solar still. Desalination, 220, 677-686. http://dx.doi.org/10.1016/j.desal.2007.01.062

Radhwan, A. M. (2004). Transient analysis of a stepped solar still for heating and humidifying greenhouse. Desalination, 161, 89-97. http://dx.doi.org/10.1016/S0011-9164(04)90043-4

Radhwan, A. M., \& Fath, H. E. S. (2005). Thermal performance of greenhouse with a built-in solar distillation system: experimental study. Desalination, 181, 193-205. http://dx.doi.org/10.1016/j.desal.2005.05.005

Sethi, V. P., \& Sharma S. K. (2007). Survey of cooling technologies for worldwide agricultural greenhouse applications. Solar Energy, 81, 1447-1459. http://dx.doi.org/10.1016/j.solener.2007.03.004

Tiwari, G. N., Singh, H. N., \& Tripathi, R. (2003). Present status of solar desalination. Solar Energy, 75, $367-373$. http://dx.doi.org/10.1016/j.solener.2003.07.005

\section{Copyrights}

Copyright for this article is retained by the author(s), with first publication rights granted to the journal.

This is an open-access article distributed under the terms and conditions of the Creative Commons Attribution license (http://creativecommons.org/licenses/by/3.0/). 